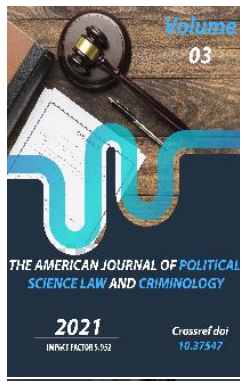

Journal Website: http://usajournalshub.c om/index,php/tajpslc

Copyright: Original content from this work may be used under the terms of the creative commons attributes 4.0 licence.

\section{Public-Private Partnership In The Republic Of Uzbekistan: Foreign Theory And Problems Of Defining The Regulatory Sector}

\author{
Bakhtiyor Kayumov \\ Head Of The Department Of The Academy Of The General Prosecutor's Office Of The Republic \\ Of Uzbekistan, Phd Student Tashkent State Law University, Uzbekistan
}

\title{
ABSTRACT
}

In this article, the author examines the problems of defining public-private partnership (PPP) from the point of view of the international theory and the experience of the Republic of Uzbekistan in this area. The views of foreign theorists, relevant international organizations, and scientists of the Republic of Uzbekistan regarding the term PPP are studied in detail. The author analyzes the relationship of PPP with the civil law contract and administrative law and concludes that the PPP agreement is classified as an unnamed contract in the Civil Code of the Republic of Uzbekistan. In conclusion, the author gives a proposal for improving the legislation of the Republic of Uzbekistan in the field of PPP.

\section{KEYWORDS}

Public-private partnership, PPP agreement, public partner, private partner, infrastructure, financing.

\section{INTRODUCTION}

The term public-private partnership (hereinafter PPP) has been formed relatively recently. M. Marsilio, G. Cappellaro and C.
Cuccurullo argue that PPP does not have a single meaning at its core and that "there is no basic concept of PPP" [1]. G. A. Hodge and C. 
Greve believe that the term PPP has been used in several areas of activity, ranging from health services and joint ventures to the provision of public infrastructure [2]. One of the most popular and constantly reinforced values of PPP today is the provision of public infrastructure using both public and private efforts.

The PPP itself is a huge family, and there are many definitions. A. Vives,

J. Benavides, and A. M. Paris, on the one hand, argue that since almost all public infrastructure projects involve the public and private sectors in one way or another, "all projects are therefore public-private partnerships" [3]. However, more narrow views were put forward by Van Ham and J. Koppenjan, according to which infrastructure PPPs can be defined as "cooperation between publicprivate entities, in which they jointly develop products and services and share the risks, costs and resources associated with these products and services" [4]. M. J. Garvin and

D. Bosso emphasized the multi-year nature of the relationship and the specific use of private finance when they defined PPPs as "a longterm contractual arrangement between the public and private sectors in which mutual benefits are sought and where ultimately (a) the private sector provides management and operational services and / or (b) exposes private finance to risk" [5]. G. A. Hodge and C. Greve similarly noted the key characteristics of today's infrastructure PPPs, such as a preference for private financing, complex contracts through a consortium, and new assumptions about accountability and governance [6].

\section{THE MAIN FINDINGS AND RESULTS}

The World Bank Group points out that PPP is a mechanism that allows the state to purchase and implement public infrastructure and / or services using the resources and experience of the private sector. Where the state is facing an aging or lack of infrastructure and needs more efficient services, partnering with the private sector can help find new solutions and attract funding [7]. This group offers a universal definition of PPP - "a long-term contract between a private party and a public organization for the provision of a public asset or service, in which the private party bears significant risk, and the responsibility of management and remuneration are related to the results of activities" [8].

In the Republic of Uzbekistan, PPP is understood as "a long-term contract between the parties from the public and private sector, concluded for the development, construction, financing and operational management of the state infrastructure by party from the private sector" [9]. So H.N. Usmanov defines PPP as an institutional and organizational alliance between the state and business for the implementation of socially important projects and programs in various industries, research, and the service sector, which defines a model of long-term and mutually beneficial cooperation between the state and business to solve socially important problems.

In the Republic of Uzbekistan, PPP is mainly implemented in the field of energy, utilities, transport, health, education, culture, and tourism. According to the Agency for the Development of Public-Private Partnership under the Ministry of Finance of the Republic of Uzbekistan [10], the largest projects with a larger amount of costs fall on the energy and 
transport sectors. For example, the construction of a new thermal power plant in the Syrdarya region with a capacity of 1,500 MW (initiated by "The International Company for water and power projects" Saudi Arabia) attracted $\$ 1,170$ million for a period of 25 years, another example is the project for the construction of a solar photo power plant with a capacity of $400 \mathrm{MW}$ in the Samarkand region (initiated by the Ministry of Energy of the Republic of Uzbekistan) - \$ 400-440 million for a period of 25 years. In the field of transport construction of the Tashkent-Samarkand toll road (initiated by the Ministry of Transport of the Republic of Uzbekistan and the Committee of Highways) with a length of $290 \mathrm{~km}$ for 30 years and a cost of $\$ 1$ billion, construction of the Tashkent-Andijan toll road (initiated by the Ministry of Transport of the Republic of Uzbekistan and the Committee of Highways) with a length of $340 \mathrm{~km}$ for 49 years and a cost of $\$ 1$ billion.

In the energy sector, 5 PPP agreements were concluded in the Republic of Uzbekistan during 2020:

1. With the company "Masdar" (UAE) on the construction of a solar photo power plant with a capacity of $100 \mathrm{MW}$ in the Navoi region;

2. With the company "Total Eren" (France) about the construction of a solar photo power plant with a capacity of $100 \mathrm{MW}$ in the Samarkand region;

3. With the company "Acwa Power" (Saudi Arabia) on the construction of a thermal power plant with a capacity of 1,500 MW in the Syrdarya region;

4. With the company "Akşa Enerji" (Turkey) on the construction of a $240 \mathrm{MW}$ thermal power plant in the Tashkent region;
5. With the company "Masdar" (UAE) on the construction of a wind power plant with a capacity of $500 \mathrm{MW}$ in the Navoi region.

In the field of energy and healthcare in the Republic of Uzbekistan, according to the Agency, major projects are in most cases proposed by foreign private initiators (Saudi Arabia, France, Turkey, the United Arab Emirates). And although the PPP Law provides for a minimum period of 3 years for a PPP agreement, projects, according to the Agency, are implemented for a period of at least 10 years.

Three parties benefit from the above PPP agreements: (1) The Republic of Uzbekistan saves the budget and receives an updated / new infrastructure; (2) the private partnerinvests their money in the form of investments and receives a profit; (3) the consumer-gets the opportunity to use high-quality infrastructure.

In our opinion, PPP relations are regulated by a civil contract.

The name of the act itself, which is the basis for PPP, is defined in the Law of the Republic of Uzbekistan "On Public-Private Partnership "(hereinafter-the Law on PPP) as a "PPP agreement". Based on articles 4 and 5 (principle of equality of the parties) It can be concluded that the PPP does not apply administrative forms of management (there is no authority and subordination), which speaks in favor of civil law regulation of PPP.

PPP is considered as a cooperation between a public and a private party to achieve a socially useful goal, where each party has a certain amount of rights and obligations, and the main issue of regulation is the property relationship, which also confirms the importance of civil legislation in PPP. That is, it is appropriate to 
consider a PPP agreement as a type of civil contract.

However, the Civil Code of the Republic of Uzbekistan (hereinafter referred to as the Civil Code of the Republic of Uzbekistan) does not provide for this type of agreement as a contract. Here we can safely use the provisions of Article 354 of the Civil Code of the Republic of Uzbekistan (the principle of freedom of contract), and note the possibility of concluding a contract by the parties and not provided for by law. For example, D. A. Samovolov notes that the PPP agreement is an independent civil law contract, which refers to unnamed contracts [11].

In the Russian Federation, the Federal Law "On Public-Private Partnership, Municipal-Private Partnership in the Russian Federation and Amendments to Certain Legislative Acts of the Russian Federation" explicitly states that a PPP agreement is a civil contract (Article 3 of the Federal Law on PPP). And it was the clarification of this provision in the Federal Law that put an end to the numerous disputes of theorists about the attribution of this agreement to an administrative-legal contract or to a civil-legal one.

In addition, the clarification of the above provision will provide an additional guarantee for the protection of the rights of the private partner from the administrative form of management.

But there is a question about the name of the act - the PPP agreement. Why do we not use the traditional and frequently used term contract when regulating legal relations between a public and a private party? In PPP, both parties strive to achieve a socially useful goal, that is, their interests are directed in one direction, although the private partner is interested in getting benefits from this cooperation, and the public partner is interested in saving their budget. It is impossible not to agree with A. A. Demin [12], who argues that the contract is usually aimed at agreeing on counterclaims to meet their needs (the goal is to buy, sell, rent), while the agreements are aimed at organizing general, rather than counter - actions. Agreement is a multi-faceted term that can be used in everyday life, as well as in legal science and law enforcement practice. In civil law, there are two main provisions of an agreement: (a) as a type of agreement or " mutual consent»; (b) the form of expression of the agreement or mutual agreement reached. The PPP agreement refers to paragraph (b), since before the conclusion of the PPP agreement itself (form of expression), the parties negotiate, reach mutual agreement.

In developed countries, this type of contract is referred to in different ways: PPP agreement, PPP agreement, PPP contract, contract agreement. But in most cases, it is the PPP contract that is used. The latter term is used by The World Bank Group [13], while the United Nations Economic and Social Commission for Asia and the Pacific (ESCAP) uses the term contract agreement [14]. The term "PPP contract" refers to contractual documents that govern the relationship between public and private parties in a PPP. These documents set out the rights and obligations of the parties, talk about the distribution of risks and mechanisms for responding to changes. In practice, a "PPP contract" may include several documents and agreements. 


\section{CONCLUSION}

Thus, it is proposed to amend article 3 of the Law of the Republic of Uzbekistan "On stateprivate partnership" concept as follows:

"the agreement on public-private partnership is a civil contract between a public partner and a private partner, concluded for a period of not less than three and not more than forty-nine years old, in the manner and on the conditions provided by this act."

\section{REFERENCES}

1. Marsilio M., G. Cappellaro, and C. Cuccurullo. 2011. "The Intellectual Structure of Research into PPPs." Public Management Review 13 (6): 763-782.

doi:10.1080/14719037.2010.539112.

2. Nodirov, D. (2020). ENSURING THE SUPREMACY OF LAW IN THE DEVELOPMENT OF AGRICULTURE IN UZBEKISTAN. European Journal of Molecular \& Clinical Medicine, 7(8), 1414-1418.

3. Hodge G. A., and C. Greve. 2017. "Private Finance: What Problems Does It Solve, and How Well?" In the Oxford Handbook of Megaproject Management, edited by B. Flyvbjerg, 362-388. Oxford: Oxford University Press.

4. Nodirov, D. (2020). Issues of improving prosecutorial control over the implementation of legislation in the field of agriculture and food. European Journal of Molecular \& Clinical Medicine, 7(2), 663-670.

5. Vives A., J. Benavides, and A.M. Paris. 2010. "Selecting Infrastructure Delivery
Modalities: No Time for Ideology or Semantics." Journal of Construction Engineering and Management 136: 412-418. doi:10.1061/(ASCE)CO.19437862.0000113.

6. Nodirov, D. (2020). Enhancing prosecutorial control over the implementation of legislation in the agricultural and food sectors. ACADEMICIA: AN INTERNATIONAL MULTIDISCIPLINARY RESEARCH JOURNAL, 10(12), 1072-1077.

7. Ikromovich, N. D. (2020). The legal basis for assigning responsibilities to the prosecutor's office in ensuring control over the implementation of legislation in the agricultural sector in Uzbekistan. ACADEMICIA: AN INTERNATIONAL MULTIDISCIPLINARY RESEARCH JOURNAL, 10(12), 10581064.

8. Van Ham H., and J. Koppenjan. 2001. "Building public-private partnerships: Assessing and Managing Risks in Port Development." Public Management Review 3 (4): 593-616. doi:10.1080/14616670110070622.

9. НОДИРОВ, А. (2020). ЎЗБЕКИСТОН ҚИШЛОқ ХЎЖАЛИГИНИ РИВОЖЛАНТИРИШДА ҚОНУН УСТУВОРЛИГИНИ ТАЪМИНЛАШ. ЮРИСТ АХБОРОТНОМАСИ, 1(4), 4449.

10. Garvin M. J., and D. Bosso. 2008. "Assessing the Effectiveness of Infrastructure Public-Private Partnership Programs and Projects." Public Works Management \& Policy 13: 162-178. doi:10.1177/1087724X08323845. 
11. Hodge, G.A., and C. Greve. 2017. "Contemporary Public-Private

Partnership: Towards a Global Research Agenda." Financial Accountability and Management 1-14. doi:10.1111/faam.12132.

12. Nodirov, D. (2020). ENSURING THE SUPREMACY OF LAW IN THE DEVELOPMENT OF AGRICULTURE IN UZBEKISTAN. European Journal of Molecular \& Clinical Medicine, 7(8), 1414-1418.

13. https://ppp.worldbank.org/publicprivate-partnership/about-publicprivate-partnerships (Date accessed 21.02.2021).

14. https://pppknowledgelab.org/guide/se ctions/3-what-is-a-ppp-defining-publicprivate-partnership (Date accessed 21.02.2021).

15. Usmanov Kh.N. Public-private partnership: foreign experience and development prospects in the Republic of Uzbekistan. "Iktisodiet va innovation technologiyalar" ilmiy electron journal. No. 5, SeptemberOctober 2015.

16. Projects. https://pppd.uz/ru/projectscustom (Date accessed 22.03.2021).

17. Samolovov D.A. Agreement on publicprivate partnership as a civil contract // Property relation in the Russian Federation. 2015. No. 8 (167). pp. 21-30.

18. Demin A.A. Contract and agreement: correlation of concepts. Bulletin of the V.N. Tatishchev Volga State University, No. 2 (78), 2013, pp. 25-34.

19. https://ppp.worldbank.org/publicprivate-partnership/standardizedagreements-bidding-documents-andguidance- manuals\#: :text=What\%20is\%20a\%20PP P\%20Contract,mechanisms\%2ofor\%20d ealing\%20with\%20change. (Date accessed 20.03.2021).

20. https://www.unescap.org/ttdw/ppp/p pp_primer/module_7_contract_ agreement_contract_management _and_dispute_resolution.html (Date accessed 20.03.2021).

21. Ikromovich, N. D. (2020). The role of prosecutor's offices in the observance of the norms of legislation in the effective use of land and water resources. ACADEMICIA: AN INTERNATIONAL MULTIDISCIPLINARY RESEARCH JOURNAL, 10(12), 1323-1327. 